\title{
TWO NEW SPECIES OF ANDINIA (PLEUROTHALLIDINAE) FROM THE CENTRAL CORDILLERA OF PERU
}

\author{
Luis Ocupa Horna ${ }^{1-3,8}$, Sebastián Vieira-Uribe ${ }^{4-6} \&$ Luis Enrique Yupanqui Godo ${ }^{7}$
}

\author{
${ }^{1}$ Departamento de Orquideología, Centro de Investigación en Biología Tropical y Conservación \\ - CINBIOTYC, Cal. Nestor Martos Mza. e Lote. 16 A.H. Almirante Miguel Grau II, Piura, Peru \\ ${ }^{2}$ Departamento de Orquideología, Instituto de Ciencias Antonio Brack, Lima, Perú \\ ${ }^{3}$ Grupo Científico Calaway Dodson: Investigación y Conservación de Orquídeas del Ecuador, Quito, \\ 170510, Pichincha, Ecuador \\ ${ }^{4}$ Sociedad Colombiana de Orquideología, Medellín, Colombia \\ ${ }^{5}$ Grupo de Investigación en Biodiversidad Tropical - GIBIOT, Jardín Botánico de Medellín, Colombia \\ ${ }^{6}$ Grupo de Investigación Schultes, Fundación Ecotonos, Cali, Colombia \\ ${ }^{7}$ Jr. Constitución 205, Huánuco, Perú \\ ${ }^{8}$ Author for correspondence: luisocupa.horna@gmail.com
}

\begin{abstract}
Two new Andinia species are described, A. barba-caprina and A. crassipetala, both found during a botanical expedition to the montane forests of the Central Cordillera of the Peruvian Andes. They are compared with morphologically similar species, and Lankester Composite Dissection Plates (LCDP) are provided. Andinia barba-caprina is more similar to A. tingomariana but is distinguished by having obovate sepals with sparsely erose margins and the lip with narrowly obtuse, short basal lobes and a group of large hairs on the abaxial surface. Andinia crassipetala is distinguished from the two most similar species, $A$. hernandoi Est.Domínguez \& S.Vieira-Uribe and A. persimilis (Luer \& Sijm) Karremans \& S.Vieira-Uribe for having thick, deltate and obtuse petals.

Key words/Palabras clave: Andes Peruanos, Andinia subgénero Andinia, Andinia subgénero Brachycladium, Andinia subgenus Andinia, Andinia subgenus Brachycladium, Epidendroideae, Huánuco, Peruvian Andes
\end{abstract}

Introduction. The Pleurothallidinae subtribe, is the largest subtribe in the Orchidaceae family, with 5481 accepted species (Karremans \& Vieira-Uribe 2020) distributed in the Neotropics. The genus Andinia (Luer) Luer (2000) is endemic to the tropical Andes. Its species are distributed from Colombia to Bolivia and can grow as epiphytes or terrestrial at mid to high elevations, from 1200 up to $3825 \mathrm{~m}$ of elevation (Wilson et al. 2017).

This genus has a complex taxonomic history, and its species have been placed in several different genera at different times. This was until Wilson et al. (2017) performed a molecular phylogenetic study and proposed five subgenera and two sections within the genus Andinia, including species that were previously treated as members of the genera Masdevalliantha Luer (1986), Neooreophilus Archila (2009), and Xeno- sia Luer (2004). Currently, Andinia has 77 recognized species (Karremans \& Vieira-Uribe 2020), nine of them in subgenus Aenigma (Luer) Karremans \& Mark Wilson, five in subgenus Andinia, 56 in subgenus Brahcylcadium (Luer) Karremans \& S.Vieira-Uribe, four in subgenus Masdevalliantha (Luer) Karremans \& Mark Wilson and finally subgenus Minuscula Karremans \& Mark Wilson with three species.

In South America, during the last decade, seven new Andinia species have been described from countries such as Colombia: Andinia lueri S.Vieira-Uribe \& Karremans (Vieira-Uribe \& Karremans 2016), A. obesa S.Vieira-Uribe \& Karremans (Vieira-Uribe \& Karremans 2017), A. auriculipetala S.Vieira-Uribe \& N.Gutiérrez (Vieira-Uribe \& Gutiérrez 2020) and A. hernandoi Est.Domínguez \& S.Vieira-Uribe (Vieira-Uribe \& Domínguez Vargas 2020); from Ecuador: 
Andinia barbata J.Ponert, M.Portilla, Chumová \& P.Trávn. (Ponert et al. 2020) and from Peru: A. sunchubambensis A.Doucette \& Janovec (Doucette \& Janovec 2016) and A. tingomariana A.G.Diaz \& Mark Wilson (Díaz et al. 2018).

In Peru, a botanical expedition carried out by the authors in 2019 to the montane forests of the Mariano Dámaso Beraún and Chaglla districts in the Huánuco region, resulted in the discovery of two new Andinia species, one of them in the subgenus Andinia and the other in the subgenus Brachycladium sect. Amplectentes. Both species are described and illustrated here.

Material and methods. Specimens were recorded in situ using Canon ${ }^{\circledR}$ Rebel T3 and EOS 7D Mark II cameras equipped with a Canon EF 100mm f/2.8L Macro USM lens. Plants were dissected under an AY11230 Barska trinocular stereo microscope. Living floral and vegetative structures were photographed with an EOS 7D Mark II camera equipped with a Canon EF $100 \mathrm{~mm}$ f/2.8L Macro USM and Raynox DCR-250 super macro snap-on lens. Obtained images were used to prepare Lankester composite dissection plates (LCDP) using Adobe Photoshop ${ }^{\circledR}$.

Descriptions were prepared from living specimens, which have been then dried and flowers preserved in alcohol and glycerin. Specimens were deposited in USM herbarium.

\section{TAXONOMIC TREATMENT}

Andinia barba-caprina Ocupa \& S.Vieira-Uribe, sp. nov. (Fig. 1, 2B-C).

TYPE: Peru. Huánuco: Leoncio Prado Province, Mariano Dámaso Beraún district, Caserío Corazón de Jesús, 1,590 m, 21 October 2019, Martel et al. 95 (holotype: USM-Spirit!).

DiAGNOSIs: Andinia barba-caprina is morphologically similar to A. tingomariana A.G.Diaz \& Mark Wilson, but is distinguished by having a sub-obovate dorsal sepal with slightly erose margins ( $v s$. elliptical, entire), broadly obovate lateral sepals with slightly erose margin (vs. elliptical, ciliate) and the lip with narrowly obtuse, short basal lobes (vs. long basal lobes, oblong to LANKESTERIANA 21(3). 2021. (C) Universidad de Costa Rica, 2021. narrowly triangular) and abaxially with a group of long hairs ( $v s$. briefly ciliate).

Plant epiphytic, ascending, up to $3.5 \mathrm{~cm}$ tall. Rhizome up to $2.3 \mathrm{~mm}$ between ramicauls. Ramicaul abbreviated, terete, 3.1-3.4 mm long, enclosed by 2 tubular, ribbed sheaths. Leaf erect, elliptic, up to $13.9 \times$ $3.7 \mathrm{~mm}$, the apex emarginate with an abaxial mucro, the base cuneate into a petiole $c a .1 \mathrm{~mm}$ long. Inflorescence a lax, successively few flowered raceme up to $12 \mathrm{~mm}$ long including the slender peduncle, floral bracts conical, acute, $0.9 \mathrm{~mm}$ long, pedicels $2.4 \mathrm{~mm}$ long. Ovary yellowish green, terete, costate, $1.9 \mathrm{~mm}$ long. Flowers with the sepals yellow with a scarlet basal, central blotch; the petals scarlet-orange and the lip amber with scarlet margins; the column scarlet with a white and burgundy apex, the anther cap white and burgundy. Sepals 3-veined, puberulous, sparsely erose, shortly caudate, abaxially carinate along the central vein; dorsal sepal sub-obovate, shallowly concave, $5.5 \times 3.3 \mathrm{~mm}$, almost free; lateral sepals broadly obovate to elliptical, $5.3 \times 3.5 \mathrm{~mm}$ connate for $c a .1 .2$ $\mathrm{mm}$. Petals reniform, puberulous, sparsely long ciliate, unguiculate, obtuse, $0.6 \times 1.3 \mathrm{~mm}$. Lip sub-reniform and laterally constricted when expanded, 3-veined, puberulous, long ciliate, rounded, $1.8 \times 1.8 \mathrm{~mm}$ expanded, with short, erect, narrowly obtuse basal lobes embracing the column, abaxially with a group of long hairs along the mid vein up to $1.8 \mathrm{~mm}$ long, adnate to the apical third of the column. Column terete, slightly dilated apically, microscopically pubescent, $2.9 \mathrm{~mm}$ long including the rostellum, anther apical, stigma apical, rostellum antrorse. Pollinia two, yellow, pyriform, with a viscidium. Anther cap elliptic, cucullate, white at the base, and vinaceous towards the top.

Eтymology: The epithet barba-caprina, is the combination of the Latin words barba (beard) and caprinus (goat), in allusion to the tuft of long hairs hanging from the lower jaw of goats, commonly known as goat beard; in comparison to the long hairs near the base of the lip of this species.

Distribution, habitat AND eCology: Andinia barbacaprina grows in secondary forests of the "yungas fluviales" ecoregion, distributed in the eastern side of the central cordillera of the Peruvian Andes, in caserío Corazón de Jesús, province of Leoncio Prado, Huánu- 


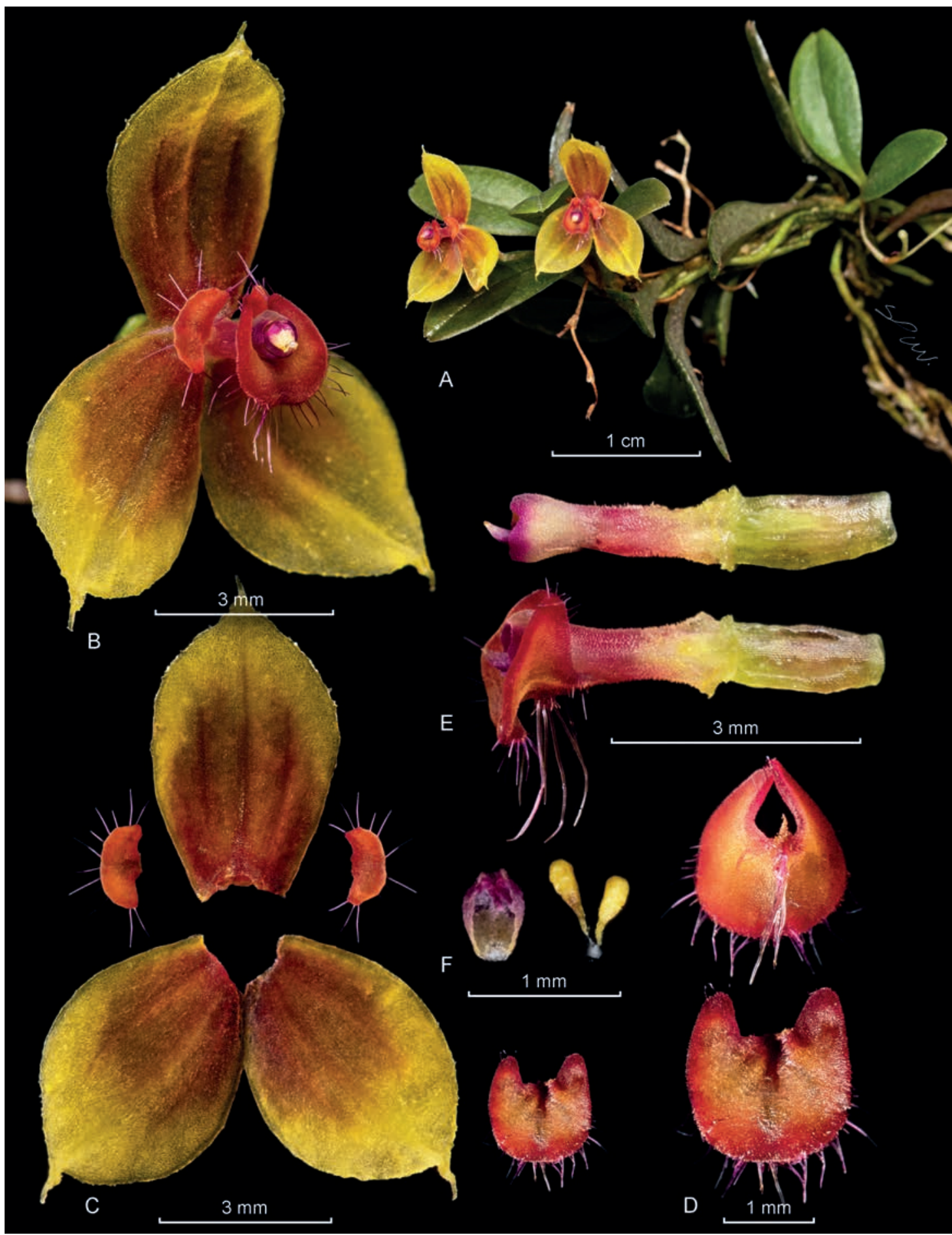

FIGURE 1. Lankester composite dissection plate of Andinia barba-caprina Ocupa \& S.Vieira-Uribe. A. Habit. B. Flower. C. Dissected perianth. D. Lip, abaxial and adaxial view. E. Ovary and column with and without lip. F. Anther cap and pollinia. Photographed and prepared by S. Vieira-Uribe from the plant that served as type. 

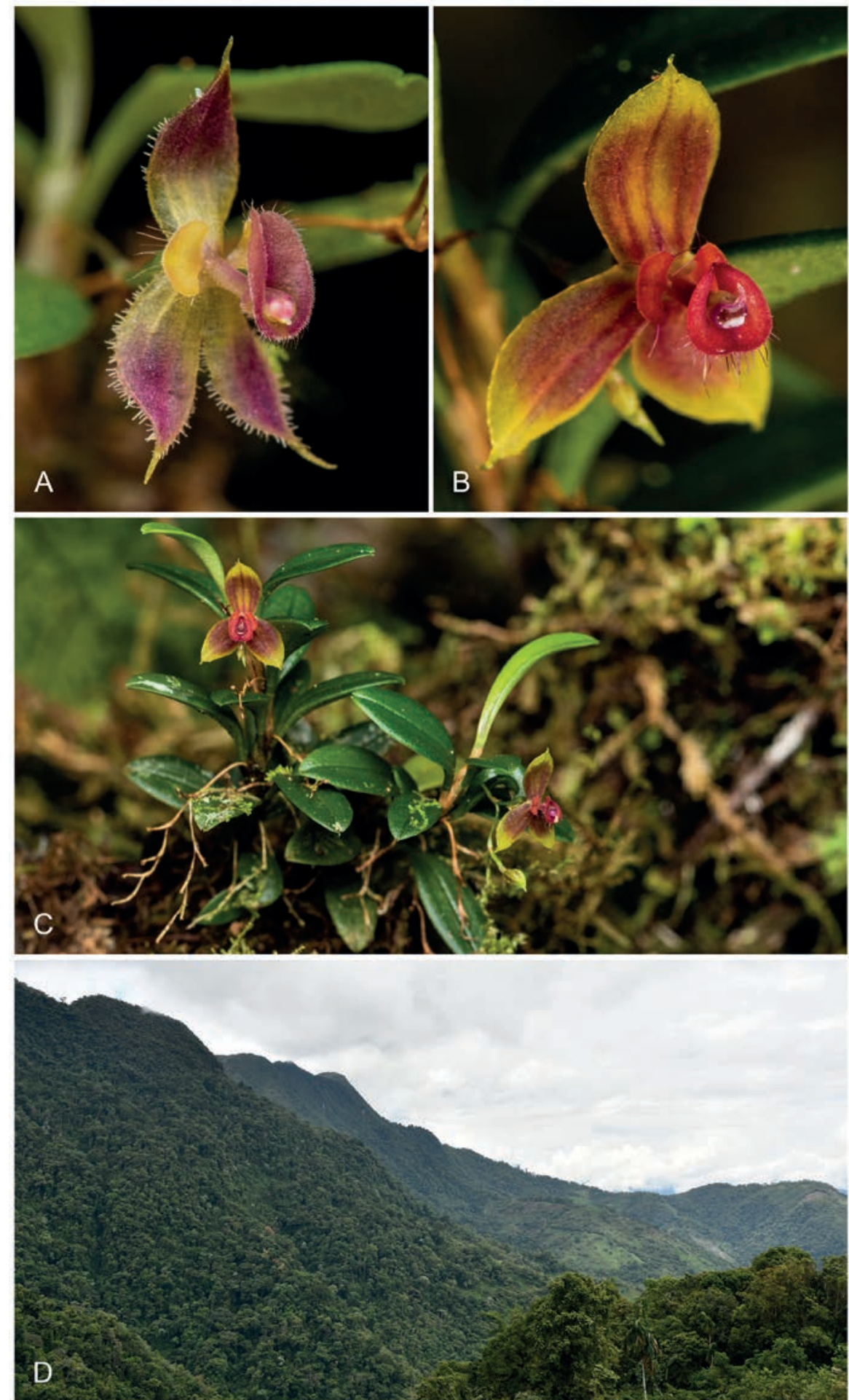

FiguRE 2. Comparison of species. A. Andinia tingomariana. B. A. barba-caprina. C. A. barba-caprina growing in-situ.

D. Habitat of A. barba-caprina. Photographs by S. Vieira-Uribe (A-C) and Luis E. Yupanqui (D). 


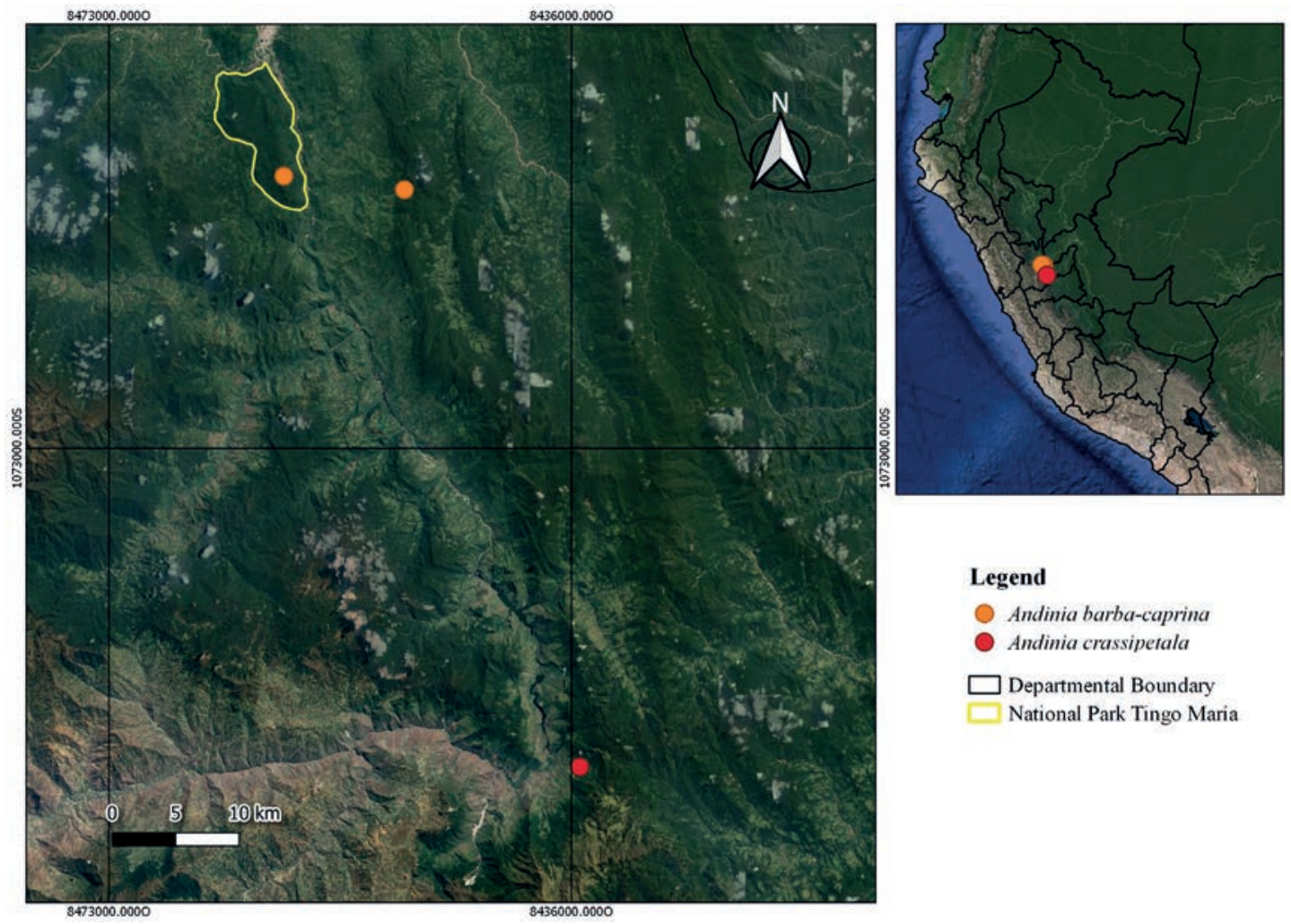

FIGURE 3. Map showing the localities of Andinia barba-caprina Ocupa \& S.Vieira-Uribe and A. crassipetala S.Vieira-Uribe \& Ocupa. Map prepared by L. Ocupa Horna.

co (Fig. 3), at an elevation of $1590 \mathrm{~m}$. It has been found growing as an epiphyte in the bark of Cyathea andina Domin, in a very humid montane forest (Fig. 2D). It has also been reported in the Tingo María National Park, which is located within a steep area in the chain of mountains known as Bella Durmiente, $10 \mathrm{~km}$ from the locality of the type, where it grows as epiphyte on branches of bushes, in sympatry with Andinia tingomariana. It was observed that the flowering of this species occurs between September and October.

Andinia barba-caprina belongs to the Andinia subgenus and is most similar to the recently described A. tingomariana, both from a vegetative and floral point of view, sharing traits such as abbreviated ramicauls, erect leaves, reniform and puberulous petals with long ciliated margins and a column terete, microscopically pubescent and slightly dilated at the apex. However, Andinia barba-caprina is clearly distinguished from A. tingomariana by presenting yel- low flowers with a central scarlet basal spot (vs. light yellow and apricot flowers), sub-obovate dorsal sepal with slightly erose margins ( $v s$. eliptic, entire), broadly obovate lateral sepals with slightly erose margin (vs. elliptical, ciliate) and the lip with narrowly obtuse, short basal lobes (vs. long basal lobes, oblong to narrowly triangular) and abaxially with a group of long hairs (vs. briefly ciliate). (Fig. 2).

Andinia crassipetala S.Vieira-Uribe \& Ocupa, sp. nov. (Fig. 4).

TYPE: Peru. Huánuco: Pachitea province, Chaglla district, Muña to Monopampa road, 2150 m, 19 October 2019, Martel et al. 96 (holotype, USM-Spirit!).

Diagnosis: Andinia crassipetala is most similar to A. hernandoi Est.Domínguez \& S.Vieira-Uribe and A. persimilis (Luer \& Sijm) Karremans \& S.Vieira-Uribe, but is easily distinguished by having thick, deltate, ob- 


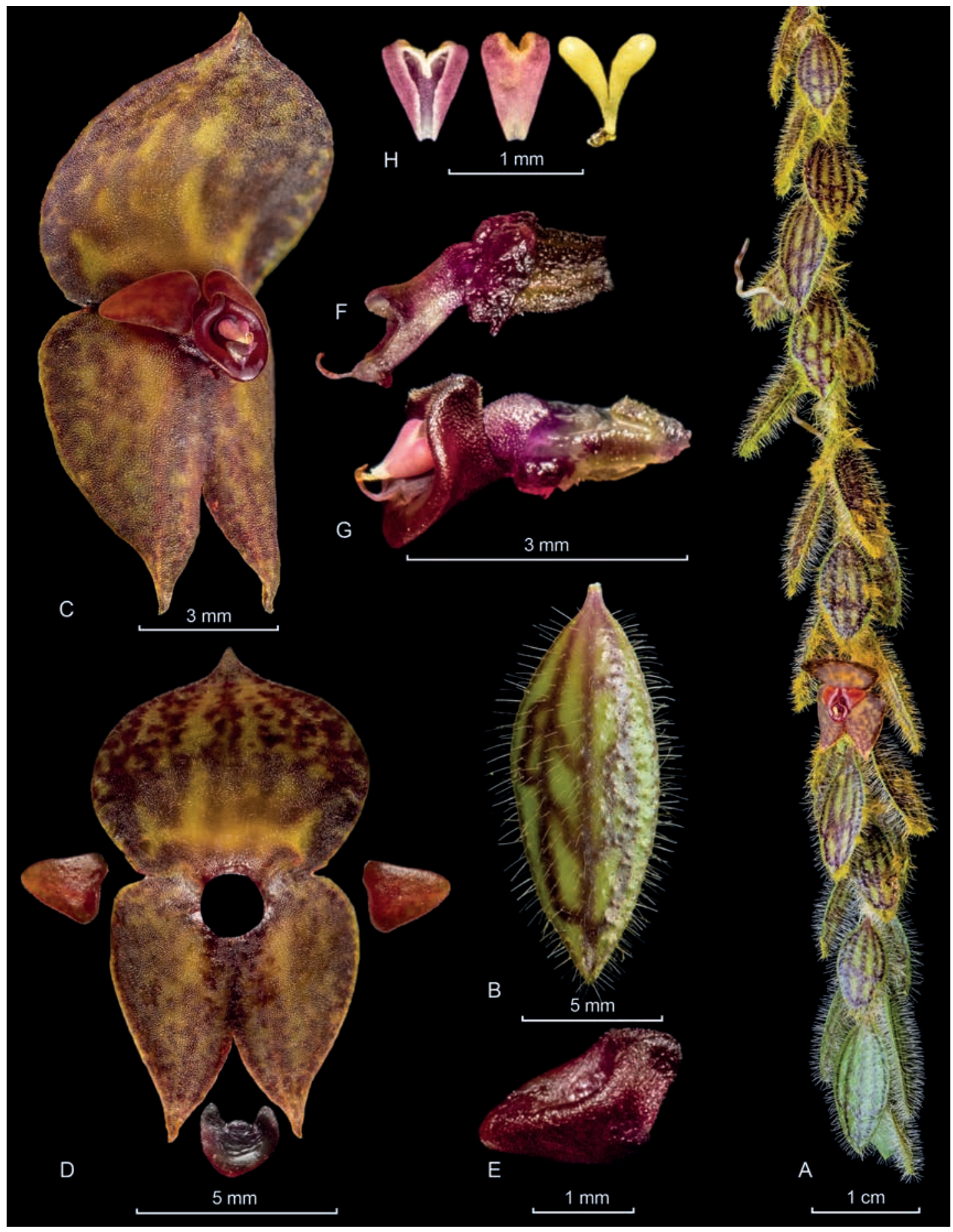

FIgURE 4. Lankester composite dissection plate of Andinia crassipetala S.Vieira-Uribe \& Ocupa. A. Habit. B. Leaf. C. Flower, oblique view. D. Dissected perianth. E. Lip, side view. F. Ovary and column (anther cap absent), side view. G. Ovary, column and lip (anther cap present), side view. H. Anther cap and pollinia. Photographed and prepared by S. Vieira-Uribe from the plant that served as type. 


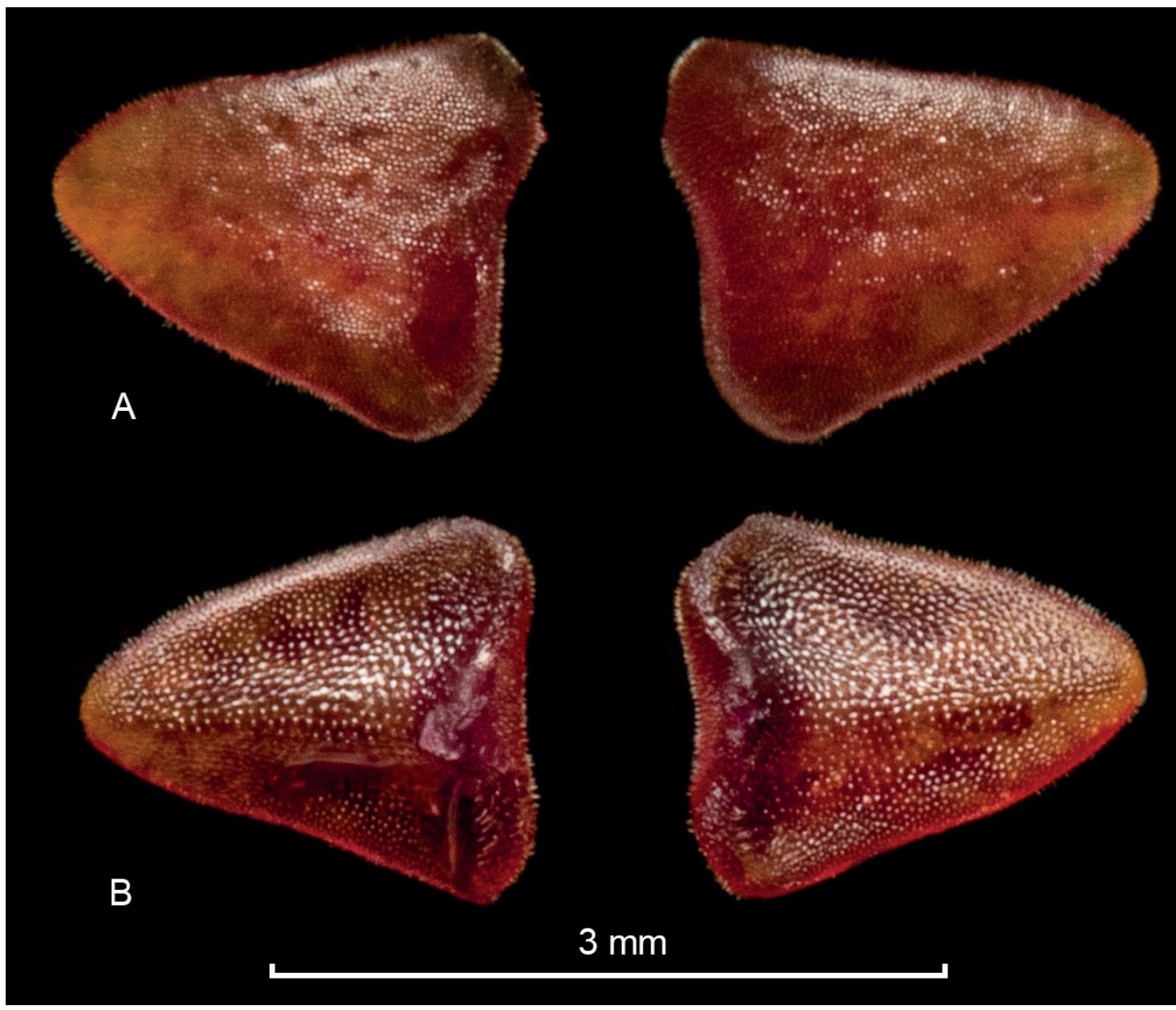

Figure 5. Detailed view of the petals of Andinia crassipetala S. Vieira-Uribe \& Ocupa. A. Adaxial view. B. Abaxial view.

Photographed and prepared by S. Vieira-Uribe from the plant that served as type.

tuse petals ( $v s$. trifurcate in A. hernandoi and oblongtriangular, subacute in A. persimilis).

Plant epiphytic, pendent, long repent, up to 43 $\mathrm{cm}$. Stem occasionally branching, 2.4-2.5 mm long between ramicauls, each segment enclosed by two infundibular, imbricating, membranaceous, pilose sheaths with pilose dilated ostia. Roots slender, $c a .0 .5 \mathrm{~mm}$ in diameter. Ramicauls ca. $1 \mathrm{~mm}$ long, enclosed by a single, infundibular, membranaceous, pilose sheath with pilose dilated ostia. Leaves suffused with purple along the reticulate veins, lanceolate, thickly coriaceous, pilose, acute, $13.9-14.8 \times 5.7-6.3 \mathrm{~mm}$, the base narrowing into a petiole $\mathrm{ca}$. $0.5 \mathrm{~mm}$ long. Inflorescence a congested, successive raceme of up to 2 flowers, placed above the leaf, $c a .4 .3 \mathrm{~mm}$ long including the
$1.8 \mathrm{~mm}$ long pedicel. Floral bract infundibular, membranaceous, pilose along the margins, ca. $1 \mathrm{~mm}$ long. Ovary costate, ca. $1 \mathrm{~mm}$ long. Flowers with saffron sepals irregularly spotted with maroon, orange-red petals and claret lip, the column vinaceous with a vinaceous anther cap suffused with amber and white. Dorsal sepal sub-orbicular, shallowly concave, marginate, acuminate, 5 -veined, $5.7 \times 7.0 \mathrm{~mm}$, connate to the lateral sepals for about $1.5 \mathrm{~mm}$. Lateral sepals ovate, slightly convex, marginate, acuminate, 3-veined, connate for about $2.4 \mathrm{~mm}$ into a bifid synsepal $6.6 \times 6.2 \mathrm{~mm}$ when expanded. Petals deltate, thick, puberulous, the apex and basal lobes obtuse, $2.0 \times 1.8 \mathrm{~mm}$. Lip reniform, 3-veined, marginally and abaxially puberulous, rounded, $1.5 \times 2.0 \mathrm{~mm}$ expanded, with short, erect, 

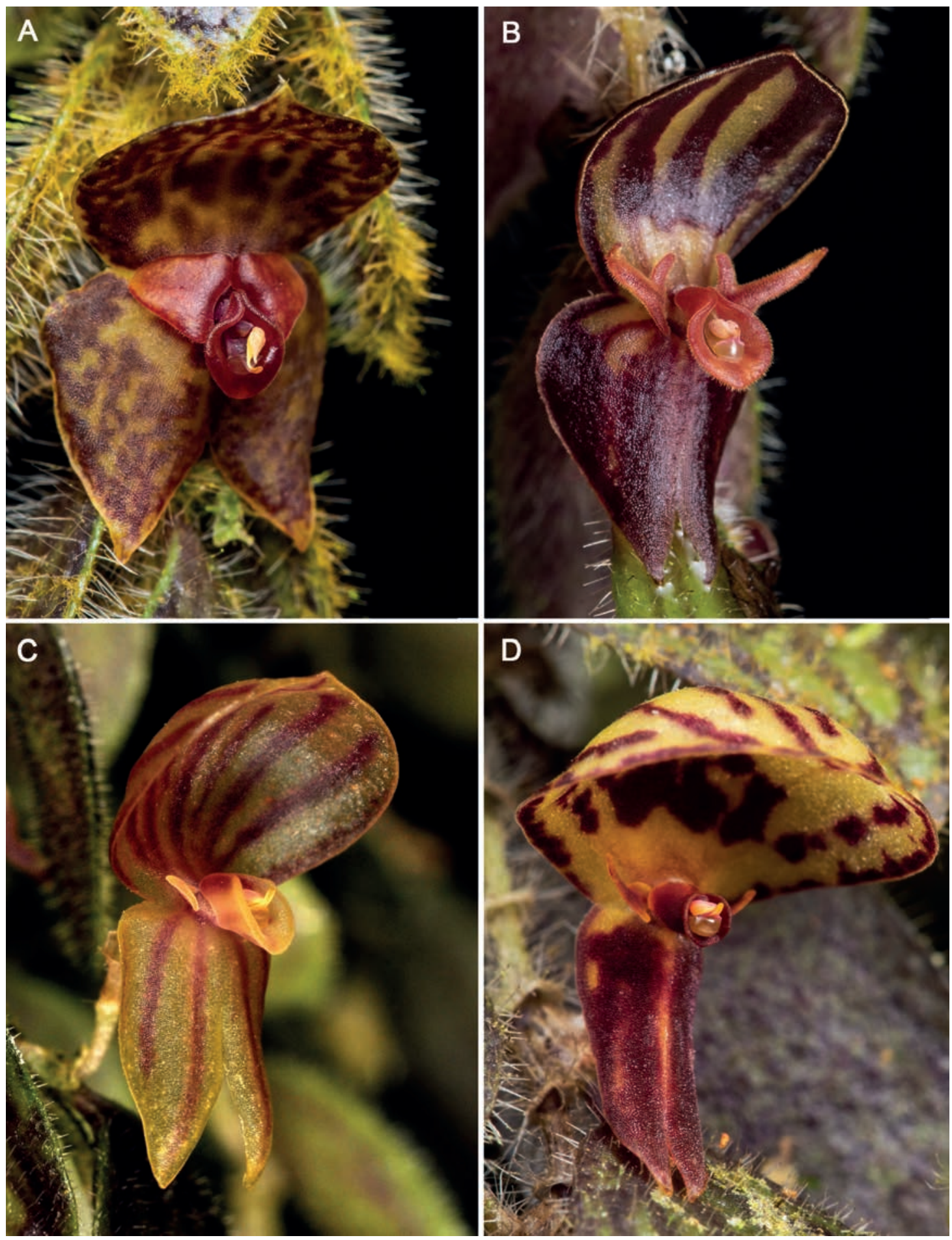

Figure 6. Comparison of Andinia crassipetala S.Vieira-Uribe \& Ocupa with its most similar species. A. A. crassipetala. B. A. hernandoi. C. A. persimilis. D. A. pilosella. Photographs by S. Vieira-Uribe (A-B, D) and Ron Parsons (C). 
obtuse basal lobes, embracing the column, adnate to the base of the column. Column terete, the anther and stigma apical, ca. $2.1 \mathrm{~mm}$ long including the antrorse, conspicuous rostellum. Pollinia two, yellow, obovoid, brought together by a drop-like viscidium. Anther cap cordate, cucullate.

Eтymology: From the Latin crassus (thick) and petalum (petals), in reference to the distinctively thick petals (Fig. 5).

Distribution, habitAT, AND ECOLOGy: Andinia crassipetala has only been seen at the type locality (Fig. 3), where it was first seen and photographed by Stig Dalström and Steve Beckendorf in 2014, and in 2019, when the authors visited the same place and were able to find a few plants growing as epiphyte, together with Dracula saulii Luer \& Sijm on the branches of a small tree, about $50 \mathrm{~cm}$ above the ground, in the edge of the secondary forest bordering the road to Monopampa village at an elevation of $2150 \mathrm{~m}$.

Andinia crassipetala is most similar to A. hernandoi and A. persimilis, sharing with them pilose leaves, an orbicular or sub-orbicular and concave dorsal sepal, and a bifid synsepal, but is differentiated by having thick, deltate petals. The only other species with lanceolate, pilose leaves supposedly found in Peru is Andinia pilosella (Rchb.f.) Karremans \& S.VieiraUribe (Luer 1994) but it is easily distinguished from A. crassipetala because it has an orbicular, deeply concave dorsal sepal that is considerably larger than the synsepal ( $v s$. sub-orbicular, shallowly concave, acuminate dorsal sepal, similar in size to the synsepal) and glabrous, narrowly triangular to linear-oblong petals (vs. thick, puberulous, deltate petals) (Fig. 6).

Acknowledgments. We thank Steve Beckendorf of the Orchid Conservation Alliance, for sharing with us the first photos of Andinia crassipetala, when he discovered it in 2014, and Stig Dälstrom for sharing details of the locality. To Oscar Rivas from Huánuco, Peru, for transporting and guiding us during the expedition in the Huánuco region and Ron Parsons for providing the photo of Andinia persimilis. Finally, we also thank Carlos Martel for the samples collected by his person, with the collection permit with Resolution of the General Directorate No. 0096-2015-SERFORDGGSPFFS, granted by SERFOR.

\section{LiterATURe Cited}

Archila, F. (2009). Neooreophilus Archila: a new genus in the Pleurothallidinae Lindl. (Orchidaceae). Revista Guatemalensis, 12, 71-91.

Díaz H., A.G., Ocupa H., L. A., Yupanqui G., L.E., \& Wilson, M. (2018). A new species of Andinia (Orchidaceae, Pleurothallidinae) from Huánuco, Peru, and the first Peruvian locality for Andinia schizopogon. Phytotaxa, 361(2), 222. https://doi.org/10.11646/phytotaxa.361.2.7

Doucette, A. \& Janovec, J.P. (2016). A new species of Andinia from Peru. Internet Orchid Species Photo Encyclopedia Nomenclature Notes, 4 a (1), 1.

Karremans, A.P., \& Vieira-Uribe, S. (2020). Pleurothallids neotropical jewels (Vol. 1). Ecuador: Imprenta Mariscal.

Luer C.A. (1994). Icones Pleurothallidinarum XI. Systematics of Lepanthes subgenus Brachycladium and Pleurothallis subgenus Aenigma subgenus Elongatia subgenus Kraenzlinella. Monographs in Systematic Botany from the Missouri Botanical Garden, 52, 35-36.

Luer, C.A. (1986). Icones Pleurothallidinarum III. Systematics of Pleurothallis. Monographs in Systematic Botany from the Missouri Botanical Garden, 20, 1-109.

Luer, C.A. (2000). Icones Pleurothallidinarum XX. Systematics of Jostia, Andinia, Barbrodia, Pleurothallis and subgenera Antilla, Effusia and Restrepioidia with Addenda to Lepanthes, Masdevallia and Pleurothallis. Monographs in Systematic Botany from the Missouri Botanical Garden, 79, 1-140.

Luer, C.A. (2004). Icones Pleurothallidinarum XXVI. Pleurothallis subgenus Acianthera and three allied subgenera. A second century of new species of Stelis of Ecuador. Epibator, Ophidion, Zootrophion. Addenda to Brachionidium, Dracula, Lepanthes, Platystele, Pleurothallis, Porroglossum, and Masdevallia. New genera and combinations. Monographs in Systematic Botany from the Missouri Botanical Garden, 95, 1-265.

Ponert, J., Andrade, M. P., Chumová, Z., \& Trávníček, P. (2020). A new species of Andinia (Pleurothallidinae, Orchidaceae) with unusual bearded flowers from Ecuador. Phytotaxa, 439(1), 77-84. https://doi.org/10.11646/ phytotaxa.439.1.5

Vieira-Uribe, S. \& Karremans, A.P. (2016). Andinia lueri, una nueva especie confundida con A. dactyla (Orchidaceae: Pleurothallidinae). Orquideología, 33, 112-122.

Vieira-Uribe, S. \& Karremans, A.P. (2017). A new species of Andinia subgen. Brachycladium (Orchidaceae: Pleurothallidinae) from Colombia. Lankesteriana, 17, 311-314. 10.15517/lank.v17i2.30210.

Vieira-Uribe, S., \& Domínguez Vargas, E. (2020). Andinia hernandoi Est.Domínguez \& S.Vieira-Uribe. In A. P. Karremans \& S. Vieira-Uribe (Eds.), Pleurothallids 
Neotropical Jewels, Vol. 1 (pp. ). Ecuador: Imprenta Mariscal.

Vieria-Uribe, S. \& Gutiérrez M., N. (2020). Andinia auriculipetala S.Vieira-Uribe \& N.Gutiérrez. Species Orchidacearum, 4(4), LCDP37.
Wilson, M., Frank, G. S., Jost, L., Pridgeon, A., VieiraUribe, S. \& Karremans, A. (2017) Phylogenetic analysis of Andinia (Orchidaceae: Pleurothallidinae) and a systematic re-circumscription of the genus. Phytotaxa, 295, 101-131. 